\title{
Mechanism of Inactivation of Hexokinase PII of Saccharomyces cerevisiae by D-Xylose
}

\author{
By R. FERNÁNDEZ, P. HERRERO, M. T. FERNÁNDEZ AND \\ F. MORENO* \\ Departamento Interfacultativo de Bioquímica, Facultad de Medicina, Universidad de Oviedo, \\ 33071 Oviedo, Spain
}

(Received 24 April 1986)

The mechanism of inactivation of hexokinase PII of Saccharomyces cerevisiae by D-xylose was characterized. Inactivation was dependent on the presence of $\mathrm{MgATP}$ and was irreversible. Inactivation involved phosphorylation of the protein. Observation of the carbon catabolite repression of selected enzymes showed that invertase and maltase synthesis were not repressed when hexokinase PII was phosphorylated.

\section{INTRODUCTION}

Hexokinase (ATP :D-hexose 6-phosphotransferase, EC 2.7.1.1) is the first enzyme of the glycolytic pathway. The enzyme isolated from yeast exists as two non-interconvertible isoenzymes, PI and PII, coded for by two different structural genes (Colowick, 1973). In addition to its hexose phosphorylating activity, yeast hexokinase PII seems to predominate during growth on glucose (Fernández et al., 1985) and its involvement in the regulation of the carbon catabolite repression of some enzymes has been demonstrated both with PI and PII transformants (Fröhlich et al., 1984; Entian et al., 1984) and by the D-xylose-induced decrease in hexokinase PII activity (Fernández et al., 1984). According to Entian \& Mecke (1982) hexokinase PII should be a bifunctional enzyme with both a catalytic and a regulatory domain.

D-Xylose is not metabolized by yeast but it non-competitively inhibits the hexokinase PII reaction and inactivates the enzyme (De la Fuente et al., 1970; Fernández et al., 1985). Yeast hexokinase PI is inactivated by D-xylose due to the phosphorylation of the enzyme protein (Menezes \& Pudles, 1976). The physiological roles of the hexokinase isoenzymes are rather different. Hexokinase PI is synthesized constitutively and hexokinase PII has both catalytic and regulatory functions. The interaction between D-xylose and the PII enzyme produces a structural change which triggers derepression by an as yet unknown mechanism.

This paper deals with the characterization of an ATP-dependent, irreversible inactivation of hexokinase PII by D-xylose.

\section{METHODS}

Materials. Sigma reagents and enzymes were used throughout. Yeast extract was obtained from Difco. Materials for electrophoresis and Bio-Gel P-10 were obtained from Bio-Rad. $\left[\gamma^{32}\right.$ P]ATP was from New England Nuclear.

Organism and growth conditions. Saccharomyces cerevisiae G-517 (CECT 1317) was inoculated into flasks with $300 \mathrm{ml}$ medium containing $1 \%(\mathrm{w} / \mathrm{v})$ yeast extract and $2 \%(\mathrm{w} / \mathrm{v})$ glucose and incubated in a rotatory shaker at $28^{\circ} \mathrm{C}$. Growth was measured as the $\mathrm{OD}_{600}$. Yeast cells were harvested at an $\mathrm{OD}_{600}$ of 2.4 and a glucose concentration of $0.5 \%$. The cells were washed twice with distilled water and resuspended in $10 \mathrm{~mm}$-potassium phosphate buffer, pH 7.0. Under these conditions hexokinase PII represents 64-70\% of the total phosphotransferase activity of the cell (Fernández et al., 1985).

Purification of hexokinase PII. Hexokinase PII was purified at $4{ }^{\circ} \mathrm{C}$ by the following procedure. S. cerevisiae cells were harvested as described above and homogenized for $20 \mathrm{~min}$ in a cell homogenizer (Vibrogen cell mill) with 
Table 1. Purification of hexokinase PII from S. cerevisiae

\begin{tabular}{lcccccc}
\multicolumn{1}{c}{ Step } & $\begin{array}{c}\text { Volume } \\
(\mathrm{ml})\end{array}$ & $\begin{array}{c}\text { Protein } \\
(\mathrm{mg})\end{array}$ & $\begin{array}{c}\text { Total } \\
\text { activity } \\
(\mathrm{U})\end{array}$ & $\begin{array}{c}\text { Specific } \\
\text { activity } \\
\left(\mathrm{U} \mathrm{mg} \mathrm{m}^{-1}\right)\end{array}$ & $\begin{array}{c}\text { Purification } \\
(- \text {-fold })\end{array}$ & $\begin{array}{c}\text { Yield } \\
(\%)\end{array}$ \\
$\begin{array}{l}\text { Cell-free extract } \\
\begin{array}{l}\text { Hydroxylapatite chroma- } \\
\text { tography }\end{array}\end{array}$ & 120 & 558 & 228 & 0.4 & 1 & 100 \\
$\begin{array}{l}\text { Chromatofocusing } \\
\begin{array}{l}\text { DEAE-Sephadex A-50 } \\
\text { chromatography }\end{array}\end{array}$ & 30 & $82 \cdot 5$ & 163 & $2 \cdot 0$ & 5 & 71 \\
& $15 \cdot 5$ & $2 \cdot 3$ & 99 & 43 & 107 & 43 \\
& & 0.45 & 59 & 132 & 330 & 26
\end{tabular}

glass beads $(0.5 \mathrm{~mm}$ in diameter) in $25 \mathrm{ml} 10 \mathrm{~mm}$-potassium phosphate buffer, $\mathrm{pH} 7.0$. The beads were removed and washed with $100 \mathrm{ml}$ buffer. The washings and extract were pooled, and centrifuged at $39000 \mathrm{~g}$ for $20 \mathrm{~min}$; the pellet was then discarded (this type of cell-free extract was used in the experiment shown in Table 2). The extract was applied to a hydroxylapatite HA-Ultrogel column $(2.5 \times 15 \mathrm{~cm})$ equilibrated with $10 \mathrm{~mm}$-potassium phosphate buffer, $\mathrm{pH} 7 \cdot 0$. Hexokinase PII activity was eluted with a $500 \mathrm{ml}$ linear gradient of $10-350 \mathrm{~mm}$ potassium phosphate buffer, $\mathrm{pH} 7.0$. The fraction volume was $5 \mathrm{ml}$. Fractions containing hexokinase PII activity were pooled and desalted over Bio-Gel P-10 with a buffer change ( $25 \mathrm{~mm}$-histidine/ $\mathrm{HCl}, \mathrm{pH} \mathrm{6} \cdot 2)$. The effluent was applied to a PBE 94 column $(1 \times 36 \mathrm{~cm})$, equilibrated with $25 \mathrm{~mm}$-histidine $/ \mathrm{HCl}$ buffer, $\mathrm{pH} 6 \cdot 2$, and fractionated with Polybuffer 74 ( $\mathrm{pH} \mathrm{4.0)}$ (Pharmacia) in a pH gradient ranging from 6.2-4.0 (fraction size $2.5 \mathrm{ml}$ ). The fractions from the chromatofocusing step that had hexokinase PII activity were pooled and ampholytes removed by filtration over Bio-Gel P-10 with a buffer change (10 mM-potassium phosphate, $\mathrm{pH} 7 \cdot 0$ ). The effluent was applied to a DEAE-Sephadex A-50 column $(1.5 \times 25 \mathrm{~cm})$ equilibrated with $10 \mathrm{mM}$-potassium phosphate buffer, $\mathrm{pH} 7.0$. Hexokinase PII activity was eluted with a linear gradient of $0-1 \mathrm{M}-\mathrm{NaCl}$ in $500 \mathrm{ml} 10 \mathrm{~mm}$-potassium phosphate buffer, $\mathrm{pH} 7 \cdot 0$. The active fractions were pooled and stored at $4^{\circ} \mathrm{C}$. The result of this purification is summarized in Table 1 .

Analytical methods. Hexokinase PII was assayed as in Fernández et al. (1985), glutamate dehydrogenase (NADdependent) as in Doherty (1970), NADH dehydrogenase as in Polakis et al. (1965), total malate dehydrogenase as in Ochoa (1955), isocitrate lyase as in Dixon \& Kornberg (1959), maltase as in Zimmermann \& Eaton (1974) and invertase as in Gascón \& Lampen (1968). Protein concentration was determined by the method of Lowry with bovine serum albumin as standard.

Inactivation of hexokinase PII. The inactivation mixture contained the following in a final volume of $1 \mathrm{ml}$ : $10 \mathrm{mM}$-potassium phosphate buffer, $\mathrm{pH} 7.0 ; 5 \mathrm{mM}$-magnesium chloride; 0,25 or $100 \mathrm{mM}$-D-xylose; 0 or $4 \mathrm{mM}$ ATP; and 100 milliunits $(\mathrm{mU})$ of hexokinase PII. The mixture was incubated at $30^{\circ} \mathrm{C}$. At appropriate time intervals, samples were taken and assayed for hexokinase PII as described above.

Phosphorylation assay. The incubation mixture contained the following in a final volume of $1 \mathrm{ml}: 10 \mathrm{~mm}$ potassium phosphate buffer, $\mathrm{pH} 7.0 ; 5 \mathrm{mM}$-magnesium chloride; $100 \mathrm{mM}$-D-xylose; and $1 \mathrm{U}$ hexokinase PII. The assay was started by the addition of $5 \mu \mathrm{Ci}(185 \mathrm{kBq})\left[\gamma^{-32} \mathrm{P}\right] \mathrm{ATP}\left[10.6 \mathrm{Ci} \mathrm{mmol}^{-1}\left(392.2 \mathrm{GBq} \mathrm{mmol}^{-1}\right)\right]$. At appropriate times after incubation at $30^{\circ} \mathrm{C}, 20 \mu \mathrm{l}$ samples were taken for the assay of enzyme activity and $15 \mu \mathrm{l}$ samples for the phosphorylation assay. The latter samples were rapidly mixed with $5 \mu \mathrm{ISDS}$ buffer $(8 \%, \mathrm{w} / \mathrm{v}, \mathrm{SDS}$; $250 \mathrm{~mm}$-Tris $/ \mathrm{HCl}$, pH 6.8; 8 mM-EDTA; 35\%, v/v, glycerol; $2.5 \%$, v/v, 2-mercaptoethanol; $0.002 \%$ bromphenol blue) and immediately boiled for $7 \mathrm{~min}$. The samples were subjected to SDS-PAGE on slab gels (Britton et ai., 1982). Gels were stained, dried, and exposed to X-Omat $S$ X-ray film for $8 \mathrm{~d}$. The incorporation of ${ }^{32} \mathrm{P}$ into hexokinase PII was measured by densitometry with a Chromoscan 3 (Joyce Loebl).

\section{RESULTS}

Inactivation of hexokinase PII induced by $\mathrm{D}-x y$ lose and $M g A T P$

Incubation of purified hexokinase PII with D-xylose (100 mM) in the presence of MgATP ( $4 \mathrm{mM}$ ) resulted in a loss of activity of hexokinase PII (Fig. 1). The inactivation was dependent on the presence of MgATP and proceeded until all enzyme activity was lost. Under these conditions the inactivation kinetics were pseudo-first-order with an apparent rate constant $K=$ $3.87 \mathrm{~h}^{-1}$. The native enzyme treated under the same conditions but in the absence of MgATP lost $50 \%$ of the initial activity with an apparent inactivation rate constant $K=0.69 \mathrm{~h}^{-1}$.

The ATP-dependent inactivation of hexokinase PII produced by D-xylose was irreversible (Fig. 2). Filtration of D-xylose-inactivated hexokinase PII through a Bio-Gel P-10 column removed the pentose from the inactivated protein but did not restore enzyme activity. Dialysis 


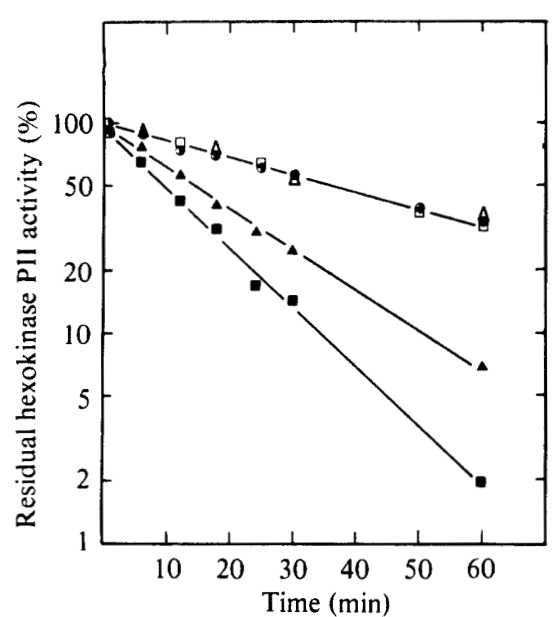

Fig. 1



Fig. 2

Fig. 1. ATP-dependent inactivation of hexokinase PII by D-xylose. Enzyme preparations were incubated at $30^{\circ} \mathrm{C}$ in $20 \mathrm{~mm}$-Tris $/ \mathrm{HCl}$ buffer, pH 7.5, with $25 \mathrm{~mm}$-xylose $(\triangle, \Delta)$ or $100 \mathrm{~mm}$-xylose $(\square$, a). Controls without pentose were processed simultaneously $(O, O) . \Delta, \square, O$, Preincubation with 4.0 mM-MgATP; $\triangle, \square, O$, preincubation without MgATP. The results are expressed as the percentage of activity remaining after the treatment.

Fig. 2. Irreversibility of the 'in vitro' inactivation of hexokinase PII by D-xylose. Purified hexokinase PII was incubated at $30^{\circ} \mathrm{C}$ for $90 \mathrm{~min}$ with $100 \mathrm{~mm}$-xylose and $4 \mathrm{~mm}-\mathrm{MgATP}$. The inactivated preparation was applied to a Bio-Gel P-10 column $(1 \times 40 \mathrm{~cm})$ and protein was eluted with 10 mm-potassium phosphate buffer, pH 7.0, in 2 ml fractions. Each fraction was assayed for hexokinase PII activity (O) and reducing sugars (xylose) $(\mathbf{A})$. Hexokinase activity of untreated enzyme.

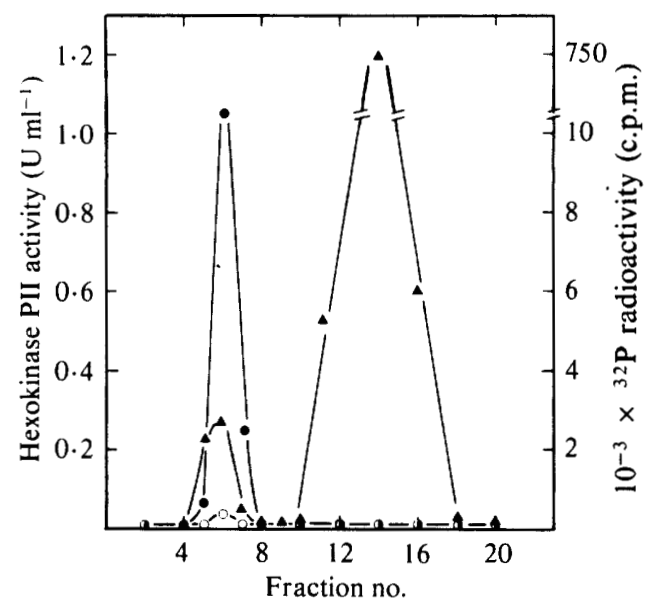

Fig. 3. Incorporation of ${ }^{32} \mathrm{P}$ into hexokinase PII induced by D-xylose. Purified hexokinase PII was incubated at $30^{\circ} \mathrm{C}$ for $90 \mathrm{~min}$ with $100 \mathrm{~mm}$-xylose and $\left[\gamma^{-32} \mathrm{P}\right] \mathrm{ATP}$. The inactivated preparation was applied to a Bio-Gel P-10 column $(1 \times 40 \mathrm{~cm})$ and protein was eluted as described in Fig. 2. Hexokinase PII activity was determined without $(O)$ or with xylose $(O) . \Delta,{ }^{32} \mathrm{P}$ radioactivity.

of D-xylose-inactivated hexokinase PII against $10 \mathrm{mM}$-potassium phosphate buffer, $\mathrm{pH} 7 \cdot 0$, also did not restore enzyme activity.

\section{Incorporation of phosphate into hexokinase PII}

When purified hexokinase PII was incubated in the presence of D-xylose and $\left[\gamma^{-32} \mathrm{P}\right] \mathrm{ATP},{ }^{32} \mathrm{P}$ was incorporated into hexokinase PII (Fig. 3). No incorporation was observed in the absence of 

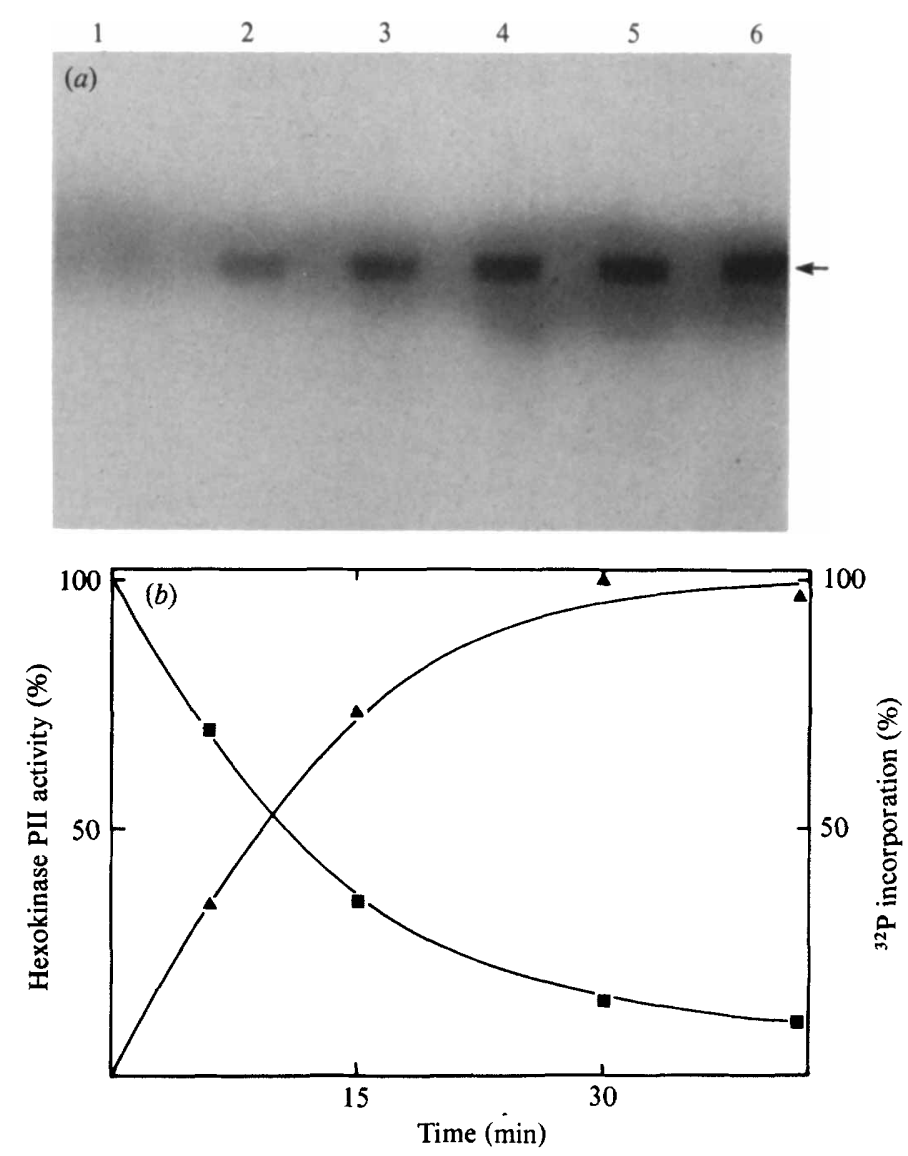

Fig. 4. Inactivation and phosphorylation of yeast hexokinase PII 'in vitro'. Purified hexokinase PII was incubated with D-xylose and [ $\gamma^{-32}$ P]ATP as described in Methods. At different times, samples were taken to measure enzyme activity and incorporation of radioactivity as described in Methods. (a) Autoradiogram showing ${ }^{32} \mathrm{P}$ incorporation into hexokinase PII. Lanes 1-6, complete mixture after 0,5 , $10,30,45$ and $60 \mathrm{~min}$ incubation, respectively. The mixture without D-xylose (after $60 \mathrm{~min}$ incubation) gave the same result as lane 1 . Arrow indicates the position of hexokinase PII in the gel. (b) Relationship between the loss of hexokinase PII activity $(\boldsymbol{\square})$ and the incorporation of ${ }^{32} \mathrm{P}(\boldsymbol{\Lambda})$.

Table 2. Effect of xylose on the catabolic repression of some enzymes from $S$. cerevisiae

\begin{tabular}{|c|c|c|c|c|}
\hline \multirow[b]{3}{*}{ Enzyme } & \multicolumn{4}{|c|}{ Specific activity $\left(\mathrm{mU} \mathrm{mg}^{-1}\right)$} \\
\hline & \multicolumn{2}{|c|}{$2 \mathrm{~h}$ culture } & \multicolumn{2}{|c|}{$6 \mathrm{~h}$ culture } \\
\hline & Glc & $\mathrm{Glc}+\mathrm{Xyl}$ & Glc & $\mathrm{Glc}+\mathrm{Xyl}$ \\
\hline Invertase & $107 \cdot 0$ & $321 \cdot 0$ & $260 \cdot 0$ & $560 \cdot 0$ \\
\hline Maltase & $9 \cdot 0$ & $33 \cdot 0$ & $31 \cdot 0$ & $180 \cdot 0$ \\
\hline Glutamate dehydrogenase & 0.0 & $0 \cdot 0$ & $16 \cdot 0$ & $18 \cdot 0$ \\
\hline NADH dehydrogenase & $7 \cdot 3$ & $8 \cdot 2$ & $21 \cdot 0$ & $21 \cdot 0$ \\
\hline Malate dehydrogenase & 1250 & 1730 & 4500 & 4100 \\
\hline Isocitrate lyase & 0.0 & $0 \cdot 0$ & 780 & 770 \\
\hline
\end{tabular}

D-xylose. As shown in Fig. 4 the incorporation of ${ }^{32} \mathrm{P}$ into the protein can be correlated with the loss of activity. From the radioactivity incorporated, the specific radioactivity of $\left[\gamma^{-32} \mathrm{P}\right] \mathrm{ATP}$, and the molarity of the enzyme in the incubation mixture, it can be calculated that $1 \mathrm{~mol}$ of phosphate per mol of enzyme was incorporated after $90 \mathrm{~min}$. 
Effect of xylose on the catabolic repression of selected enzymes

The relationship between the xylose-induced decrease in hexokinase PII activity and the derepression of invertase synthesis in yeast has been described by Fernández et al. (1984). When xylose was added to cells growing in a yeast nitrogen base (or yeast extract) plus glucose medium, catabolic repression was suppressed, as is shown by the large increase in invertase levels even if the glucose concentration remained high. Table 2 summarizes the effect of xylose on the activity of enzymes selected as representative of different pathways: only invertase and maltase were freed from catabolite repression.

\section{DISCUSSION}

Hexokinase PII has been reported to be of major importance in carbon catabolite repression (Fröhlich et al., 1984; Entian et al., 1984; Fernández et al., 1984). The hexokinase PII molecule provides a repression signal for certain enzymes when glucose is present in the culture medium. This requires some kind of change in enzyme conformation in response to the presence of carbon sources such as glucose or fructose.

Work on hex-lr mutants indicated that these are two different domains in the hexokinase PII molecule, one with catalytic properties, the other with regulatory properties (Entian \& Fröhlich, 1984). The catalytic centre of hexokinase PII was unaffected in these mutants. The mutation affected the regulatory domain, which is responsible for the glucose repression of invertase, maltase, malate dehydrogenase and respiratory enzymes.

Our results show that the inactivation of yeast hexokinase PII by xylose and MgATP is related to the phosphorylation of the protein. Simultaneous with the phosphorylation, the synthesis of invertase and maltase was derepressed but the synthesis of malate dehydrogenase, NADH dehydrogenase, glutamate dehydrogenase and isocitrate lyase was repressed.

These experiments also showed that since malate dehydrogenase levels were unaffected, the carbon catabolite repression signal produced by the phosphorylated enzyme was different from that produced in hex-Ir mutants. The xylose-induced phosphorylation of hexokinase PII may produce a conformational change in the enzyme which could provide the triggering signal for invertase and maltase derepression. Although the essential role of hexokinase PII in triggering glucose repression seems to be established, the molecular mechanism is still unknown. The identification of phosphorylated hexokinase PII isoenzyme under culture derepression conditions could give a direct physiological role to the observed covalent modification of the enzyme.

The authors would like to thank Professor S. Gascón for his interest in this work and for the many stimulating discussions. This work was supported by Comisión Asesora de Investigación Científica y Técnica.

\section{REFERENCES}

Britton, P., Murfitt, D., Parra, F., JonesMortimer, M. C. \& Kornberg, H. L. (1982). Phosphotransferase-mediated regulation of carbohydrate utilisation in Escherichia coli K12: identification of the products of genes on the specialised transducing phages $\lambda$ iex (crr) and $\lambda$ gsr (tgs). $E M B O$ Journal 1, 907-911.

Colowick, S. P. (1973). The hexokinases. In The Enzymes, vol. 9, 3rd edn, pp. 1-48. Edited by P. D. Boyer. New York: Academic Press

De la Fuente, G., Lagunas, R. \& Sols, A. (1970). Induced fit in yeast hexokinase. European Journal of Biochemistry 16, 226-233.

Dixon, G. H. \& Kornberg, H. L. (1959). Assay methods for key enzymes of the glyoxylate cycle. Biochemical Journal 72, 3p.

DOHERTY, D. (1970). L-Glutamate dehydrogenases (yeast). Methods in Enzymology 17, 850-856.
EnTIAN, K. D. \& Fröhlich, K. U. (1984). Saccharomyces cerevisiae mutants provide evidence of hexokinase PII as a bifunctional enzyme with catalytic and regulatory domains for triggering carbon catabolite repression. Journal of Bacteriology 158, 29-35.

ENTIAN, K. D. \& MECKE, D. (1982). Genetic evidence for a role of hexokinase isozyme PII in carbon catabolite repression in Saccharomyces cerevisiae. Journal of Biological Chemistry 257, 870-874.

Entian, K. D., Kopetzki, E., Fröhlich, K. U. \& MECKE, D. (1984). Cloning of hexokinase isoenzyme PI from Saccharomyces cerevisiae: PI transformants confirm the unique role of hexokinase isoenzyme PII for glucose repression in yeasts. Molecular and General Genetics 198, 50-54.

Fernández, R., Herrero, P., Gascon, S. \& Moreno, F. (1984). Xylose induced decrease in hexokinase PII activity confers resistance to carbon catabolite 
repression of invertase in Saccharomyces carlsbergensis. Archives of Microbiology 139, 139-142.

Fernández, R., Herrero, P. \& Moreno, F. (1985). Inhibition and inactivation of glucose-phosphorylating enzymes from Saccharomyces cerevisiae by D-xylose. Journal of General Microbiology 131, 2705-2709.

FröhliCh, K. U., ENTIAN, K. D. \& MECKE, D. (1984). Cloning and restriction analysis of the hexokinase PII gene of the yeast Saccharomyces cerevisiae. Molecular and General Genetics 194, 144-148.

Gascon, S. \& LAmpen, J. O. (1968). Purification of the internal invertase of yeast. Journal of Biological Chemistry 243, 1567-1572.
Menezes, L. C. \& Pudles, J. (1976). Studies on the active site of yeast hexokinase. Specific phosphorylation of a serine residue induced by the xylose and ATPMg. European Journal of Biochemistry 65, 41-47. OCHOA, S. (1955). Malic dehydrogenase from pig heart. Methods in Enzymology 1,735-739.

Polakis, E. S., Bartley, W. \& Meek, G. A. (1965). Changes in the activities of respiratory enzymes during the aerobic growth of yeast on different carbon sources. Biochemical Journal 97, 298-302.

ZimmermanN, F. K. \& EATON, N. R. (1974). Genetics of induction and catabolite repression of maltase synthesis in Saccharomyces cerevisiae. Molecular and General Genetics 134, 261-272. 